\title{
Socialization of Tempe For Household Industry Making in Indigenous Papua Communities in Malanu Malaimsimsa District, Sorong City, West Papua
}

\author{
Ibrahim $^{1}$, Sukmawati ${ }^{* 2}$ \\ ${ }^{I}$ Fakultas Keguruan dan Ilmu Pendidikan Universitas Muhammadiyah Sorong \\ ${ }^{2}$ Fakultas Perikanan Universitas Muhammadiyah Sorong \\ (Universitas Muhammadiyah Sorong, Kota Sorong Distrik Malaimsimsa, 98419 Jl. Pendidikan No. 27) \\ *Correspondence: sukmawati.sw91 @ gmail.com; Tel.: +62-852-382-25362
}

Diterima19 September, Disetujui 25 September Dipublikasikan 30 November 2018

\begin{abstract}
The Socialization of Tempe production on Papua ethnic aimed to give some information of microorganism benefits in housing industry; to socialize the process of making Tempe; and to give suggestion to the society in order to use some certain microorganism in making their business. This study used library research; gave some information about the advantage of microorganism in making Tempe, how to product Tempe in housing scale. By the end of the presentation, it showed that most of Papua ethnic had no any experiences in making Tempe. It can be seen by their enthusiasm in attending the socialization and in learning how to make Tempe.
\end{abstract}

Keywords - Socialization, Tempe Production, Papua Ethnic

\section{Pendahuluan}

Kedelai adalah sumber protein nabati, protein yang terdapat pada kedelai sebesar 35\%-43\%[1]. Di Indonesia, sekitar $90 \%$ kedelai diolah manjadi bahan pangan. Pengelohan kedelai sebagai bahan pangan didominasi oleh tempe, sebanyak $50 \%$ sisanya diolah menjadi tahu, oncom, dan susu kedelai[2].

Tempe adalah makanan khas Indonesia sedangkan definisi menurut SNI NO. 01-3144-1992 tempe adalah produk makanan hasil fermentasi biji kedelai oleh jamur tertentu, berbentuk padatan kompak dan berbau khas serta, berwarna putih atau sedikit keabuabuan[3]. Pembuatan Tempe dilakukan yang mudah dicerna oleh manusia [4]. Tempe mempunyai ciri-ciri berwarna dengan proses fermentasi, yaitu dengan menumbuhkan jamur Rhizopus oryzae pada kedelai matang yang telah dilepaskan kulit epidermisnya. Tempe mengandung berbagai nutrisi yang diperlukan oleh tubuh seperti protein, lemak, karbohidrat, dan mineral. Kandungan protein pada tempe sebesar $18,3 \%$ [2].

Beberapa hasil penelitian menunjukkan bahwa zat gizi tempe seperti protein dan karbohidrat, lebih mudah dicerna, diserap, dan dimanfaatkan oleh tubuh. Hal demikian disebabkan oleh jamur Rhizopus sp. yang tumbuh pada kedelai, karena kemampuannya menghidrolisis senyawa-senyawa kompleks menjadi senyawa sederhana putih, tekstur kompak dan flavor spesifik. Warna putih disebabkan 
adanya miselia jamur yang tumbuh pada permukaan biji kedelai. Tekstur yang kompak juga disebabkan oleh miselia-miselia jamur yang menghubungkan antara biji-biji

Tempe yang bagus, tampak keras dan tidak kering, tidak mengandung kotoran dan tidak tercampur bahan lain. Tempe segar tidak dapat disimpan lama karena tempe hanya dapat disimpan dalam waktu 2x24jam. Lebih dari 48jam jamur tempe mati dan selanjutnya akan tumbuh bakteri atau mikroba perombak protein akibatnya tempe cepat busuk [5].

Mikroorganisme bagi sebagaian masyarakat dikenal sebagai kuman yang berkaitan erat dengan penyakit, infeksi, dan kotoran. Padahal disamping efek merugikan yang ditimbulkan mikroorganisme, banyak sekali dampak positif dari mikroorganisme bagi kehidupan kita. Sebagai contoh tempe merupakan produk olahan yang sudah tersebar luas bagi masyarakat Indonesia, tanpa bantuan mikroorganisme Rhizopus oryzae yang terdapat di dalam ragi tempe, maka kacang kedelai sebagai bahan baku tidak dapat berubah menjadi tempe. Informasi seperti ini yang akan disampaikan kepada masyarakat asli Papua sekaligus memberikan informasi cara pembuatan tempe pada skala rumah tangga. Ilmu mikrobiologi terus berkembang sangat pesat saat ini diantaranya di bidang

\section{Kerangka Pemecahan Masalah}

Kandungan gizi dan pentingnya mengkonsumsi tempe masih belum disadari oleh sebagian masyarakat, khususnya masyarakat asli kedelai tersebut. Terjadinya degradasi komponen-komponen dalam kedelai dapat menyebabkan terbentuknya flavor spesifik setelah fermentasi.

kesehatan, lingkungan, pangan, dan industri.

Beberapa jenis produk olahan yang muncul dengan memanfaatkan mikroorganisme baik bakteri atau jamur yang sudah banyak dikenal masyarakat diantaranya adalah yogurt, keju, tempe, oncom, dan lain sebagainya. Proses pengolahan bahan pangan, mikroba berperan sebagai starter fermentasi. Bahan pangan yang telah difermentasi pada umumnya akan memiliki masa simpan yang lebih lama, juga dapat meningkatkan atau bahkan memberikan cita rasa baru dan unik pada makanan tersebut.

Kegiatan sosialisasi pembuatan tempe berbasis mikrobiologi dimaksudkan untuk memberikan informasi kepada masyarakat. Khususnya masyarakat asli papua tentang peranan menguntungkan mikroorgansime dalam bidang industri pangan, memberikan informasi kepada masyarakat mengenai pembuatan tempe pada skala industri rumah tangga secara sederhana, mendorong masyarakat agar dapat menerapkan prinsip-prinsip pemanfaatan mikroorganisme dalam bidang industri pangan sebagai bekal dalam berwirausaha.

Papua. Begitu pula dengan cara pembuatannya, mereka masih awam. Dalam hal ini yang perlu ditekankan ialah pemberian starter terhadap 
pembuatan tempe sangat menentukan keberhasilan pembuatan tempe. Berdasarkan hal itu, pemaparan diberikan secara intensif untuk memberikan informasi yang

\section{Solusi yang Ditawarkan}

Pada kegiatan ini, solusi yang ditawarkan adalah memberikan sosialisasi tentang peranan menguntungkan mikroorganisme dalam bidang industri pangan yang dilanjutkan dengan diskusi antara pemateri dengan mitra/masyarakat asli Papua. Materi sosialisasi meliputi: pendahuluan, penjelasan tentang mikroorganisme yang menguntungkan dalam bidang industri pangan, contoh produk pangan yang dibuat dengan bantuan mikroganisme dan metode pembuatan produk pangan tersebut.

\section{Prosedur Pelaksanaan}

Pemateri melakukan presentasi yang selanjutnya diskusi dengan mitra/masyarakat asli Papua. Penyampaian materi berupa prosedur cara kerja pembuatan tempe. Cara pembuatan tempe ialah: Kedelai direbus hingga matang $( \pm 1,5$ jam $)$ pada panci, setelah matang dipindahkan ke baskom yang berisi air dan direndam selama \pm 15 jam. Setelah perendaman kedelai dipindahkan ke tempat yang baru, kemudian digiling dengan tujuan

\section{Hasil dan Diskusi}

\section{Persiapan kegiatan pengabdian kepada masyarakat}

Sebelum kegiatan dilaksanakan maka dilakukan persiapan - persiapan kegiatan sebagai berikut: dibutuhkan. Dengan dasar keilmuan yang pihak pelaksana miliki. Sehingga mitra kegiatan dapat membuat tempe dengan mudah dan benar.

agar kedelai pecah menjadi dua dan kulit kedelai bisa lepas. Setelah pemecahan dan pelepasan kulit kedelai dilakukan pencucian hingga ( $3 x$ bilas) bersih dan kulit kedelai dibuang. Setelah dilakukan pembilasan dilakukan penirisan kedelai yakni memisahkan air bilasan dan kedelai.

Kedelai yang telah bersih ditambahkan ragi dengan takaran 12,5 $\mathrm{kg}$ kedelai : 1 potong ragi dengan ukuran 20x5 $\mathrm{cm}$ jika musim hujan, sedangkan jika musim panas kedelai $12,5 \mathrm{~kg}: 1 / 2$ potong ragi dengan ukuran $20 \times 5 \mathrm{~cm}$. Setelah pencampuran antara ragi dan kedelai diaduk hingga merata.

Kedelai+ragi yang telah diaduk, dimasukkan ke dalam plastik pembungkus yang telah dilubangi, kemudian di rekatkan dengan menggunakan lilin. Kedelai yang telah diinokulasikan ragi diratakan kemudian diinkubasi pada suhu ruang di atas rak bambu selama 2 hari. Setelah inkubasi selama 2 hari tempe siap dikonsumsi ataupun dijual.

1. Melakukan studi pustaka tentang manfaat tempe dan metode produksi dalam skala kecil (skala rumah tangga). 
2. Menentukan waktu pelaksanaan dan lamanya kegiatan pengabdian masyarakat.

4. Menentukan dan mempersiapkan materi yang akan disampaikan

Pelaksanaan kegiatan pengabdian kepada masyarakat

Kegiatan pengabdian kepada masyarakat berlangsung pada hari sabtu, 18 November 2017 pukul 10.00 - 12.00 WIT. Kegiatan dilangsungkan di kelurahan Malanu, distrik Berdasarkan diskusi, tanya jawab selama kegiatan berlangsung, kegiatan pengabdian kepada masyarakat ini mendapat respon positif dari masyarakat. Hal ini dapat dilihat dari antusiasme masyarakat yang mengikuti pelatihan dan peran aktif para masyarakat selama kegiatan berlangsung.

Kegiatan pengadian kepada masyarakat memberikan hasil sebagai berikut:

\section{Kualitas produk yang harus dicapai dalam pembuatan tempe}

Kualitas tempe yang dihasilkan harus menjadi hal prioritas. Bau dinyatakan normal jika tidak tercium bau asin. Warna normal adalah putih keabu-abuan yang dihasilkan dari proses fermentasi tempe. Rasa yang normal dinyatakan bila tidak terasa rasa asin, tekstur tempe yang padat jika seluruhnya diselimuti oleh hifa Rhizopus sp.Usaha pembuatan tempe harus memegang prinsip kerja cepat dengan hasil yang memuaskan. Sehingga konsumen akan tetap melirik usaha tersebut dan menjadi pelanggannya, jika dikonversi dalam kegiatan wirausaha skala rumah dalam kegiatan pengabdian kepada masyarakat.

Malaimsimsa, kota Sorong yang dihadiri 20 orang peserta (dalam hal ini masyarakat asli Papua). Kegitan yang dilakukan berupa penyampaian materi dan diskusi 1. Meningkatnya pengetahuan dan pemahaman masyarakat asli Papua tentang kandungan gizi tempe bagi kesehatan.

2. Meningkatnya pengetahuan keterampilan masyarakat asli Papua dalam membuat tempe secara sederhana berbasis mikrobiologi, sehingga dimungkinkan peserta dapat membuat tempe di rumah masing-masing baik untuk kebutuhan keluarga maupun untuk dijadikan wirausaha.

tangga. Tempe yang telah diinkubasi pada suhu ruang akan tumbuh miselium dari ragi yang digunakan. Tumbuhnya hifa-hifa ini menyebabkan tempe berwarna putih, mengeluarkan bau khas dan memiliki tekstur padat. Uraian mengenai ciri-cir tempe juga dikatakan oleh [4] bahwa tempe mempunyai ciri-ciri berwarna putih, tekstur kompak dan rasa khas. Warna putih disebabkan adanya miselia jamur yang tumbuh pada permukaan biji kedelai. Tekstur yang kompak juga disebabkan oleh miselia-miselia jamur yang menghubungkan antara biji-biji kedelai tersebut. Terjadinya degradasi 
komponen-komponen dalam kedelai dapat menyebabkan terbentuknya rasa spesifik setelah fermentasi.

Bau dinyatakan normal jika tidak tercium bau asing. Warna normal adalah putih keabu-abuan yang dihasilkan dari proses fermentasi tempe. Rasa yang normal dinyatakan bila tidak terasa rasa asin, tekstur tempe yang padat jika seluruhnya diselimuti oleh hifa Rhizopus sp. [3]. Kualitas tempe amat dipengaruhi oleh kualitas starter yang digunakan dalam menginokulasikannya. Inokulum tempe disebut juga sebagai starter tempe, dan banyak pula yang menyebutkan dengan nama ragi tempe. Starter tempe adalah bahan yang mengandung biakan jamur tempe, digunakan sebagai agen pengubah kedelai rebus menjadi tempe akibat tumbuhnya jamur tempe pada kedelai dan terjadinya fermentasi menyebabkan kedelai berubah sifat/karakteristiknya menjadi tempe [4].

Peyimpanan tempe tidak bolehh lebih dari 48 jam, sebab jamur tempe akan mati dan selanjutnya akan tumbuh bakteri atau mikroba perombak protein akibatnya tempe membusuk[5]. Proses pembuatan tempe dilakukan pencucian, perebusan dan perendaman. Langkah-langkah tersebut dilkukan karena masingmasing memiliki tujuan, berikut tujuan dari tiap langkah pembuatan tempe. Pencucian bertujuan untuk menghilangkan kotoran yang melekat. Perebusan bertujuan untuk melunakkan biji kedelai dan memudahkan dalam pengupasan kulit serta bertujuan untuk menonaktifkan tripsin inhibitor yang ada dalam biji kedelai. Selain itu perebusan bertujuan untuk mengurangi bau langu dari kedelai dan dengan perebusan akan membunuh bakteri yang yang kemungkinan tumbuh selama perendaman [6].

Perendaman bertujuan untuk melunakkan biji dan mencegah pertumbuhan bakteri pembusuk selama fermentasi. Ketika perendaman, pada kulit biji kedelai telah berlangsung proses fermentasi oleh bakteri yang terdapat di air terutama oleh bakteri asam laktat. Perendaman juga betujuan untuk memberikan kesempatan kepada keping-keping kedelai menyerap air sehingga menjamin pertumbuhan jamur menjadi optimum. Keadaan ini tidak mempengaruhi pertumbuhan jamur tetapi mencegah berkembangnya bakteri yang tidak diinginkan. Perendaman ini dapat menggunakan air biasa atau air yang ditambah asam asetat sehingga $\mathrm{pH}$ larutan mencapai 4-5 [6].

Selama proses perendaman, biji mengalami proses hidrasi, sehingga kadar air biji naik sebesar kira-kira dua kali kadar air semula, yaitu mencapai 62-65\%. Proses perendaman memberi kesempatan pertumbuhan bakteribakteri asam laktat sehingga terjadi penurunan $\mathrm{pH}$ dalam biji menjadi sekitar 4,5-5,3. Bakteri yang berkembang pada kondisi tersebut antara lain Lactobacillus casei, Streptococcus faecium, dan Streptococcus epidermidis. Kondisi ini memungkinkan terhambatnya pertumbuhan bakteri yang bersifat patogen dan pembusuk yang tidak tahan terhadap asam. Selain itu, peningkatan kualitas organoleptiknya juga terjadi dengan terbentuknya aroma dan rasa yang unik [6]. 
Proses hidrasi terjadi selama perendaman dan perebusan biji. Makin tinggi suhu yang dipergunakan makin cepat proses hidrasinya, tetapi bila perendaman dilakukan pada suhu tinggi menyebabkan penghambatan pertumbuhan bakteri sehingga tidak terbentuk asam [7]. Salah satu faktor yang penting dalam terjadinya perubahan selama perendaman adalah

\section{Kesimpulan}

Melalui kegiatan tersebut, masyarakat dapat mengetahui pentingya peranan mikroorganisme dalam bidang industri pangan. Selaian daripada itu masyarakat khususnya asli warga papua mampu memproduksi tempe tingkat skala rumah tangga

\section{Ucapan Terima Kasih}

Ucapan terima kasih diberikan kepada kepala kelurahan Malanu yang telah memberikan izin dan tempat workshop atas kegiatan ini, dan juga

\begin{abstract}
terbebasnya senyawa-senyawa isoflavon dalam bentuk bebas (aglikon), dan teristimewa hadirnya Faktor-II $\quad(6,7,4, \quad$ tri-hidroksi isoflavon), yang terdapat pada tempe tetapi tidak terdapat pada kedelai, ternyata berpotensi tinggi (dibandingkan dengan isoflavon lainnya) sebagai antioksidan [8].
\end{abstract}

dengan cita rasa yang khas sesuai cita rasa tempe pada umumnya. Dengan mengetahui prinsip-prinsip pemanfaatan mikroorganisme dalam bidang industri pangan, maka dapat dijadikan bekal dalam berwirausaha oleh masyarakat asli papua dan atau masyarakat setempat.

ucapan terima kasih kepada seluruh warga asli Papua di kelurahan Malanu telah antusias dalam kegiatan pengabdian masyarakat.

\section{Pustaka}

[1] Margono. 2000. Tempe. Jakarta: Buku panduan teknologi pangan. Pusat informasi wanita dalam pembangunan PDII-LIPI bekerjasama dengan Swiss Development Cooperation.

[2]Ginting E. 2010. Petunjuk teknis produk olahan Kedelai: Materi pelatihan agribisnis bagi KMPH. Malang: Balai penelitian Kacang-kacangan dan umbi-umbian.

[3]SNI. 2009. Tempe Kedelai. Jakarta: Badan Standar Nasional SNI 3144:2009.

[4]Kasmidjo RB. 1990. Tempe: Mikrobiologi dan Kimia Pengelohan serta pemanfaatannya. Yogyakarta: PAU Pangan dan Gisi UGM.

[5]Sarwono, B. 1996. Membuat Tempe dan Oncom. Penerbit Swadaya. Jakarta.

[6]Ali I. 2008. Buat Tempe Yuuuuk. http:www//iqbalali.com/2008/05/07/buat-tempeyuuuuk//. (Diakses pada tanggal 28 September 2017).

[7]Hidayat N. 2008. Fermentasi Tempe. http://ptp2007.files.wordpress.com/ 2008/03/fermentasi-tempe.pdf. (Diakses pada tanggal 28 September 2017).

[8]Gyorgy PK, Murata, Ikehata H. 1964. Antioxidants Isolated From Fermented Soybeans Tempeh. Nature. 203: 872-875 